\title{
REGIONAL PROCESSES IN HUNGARY FROM PHARE TO SMART SPECIALISATION
}

\author{
Viktória, JÓZSA ${ }^{\text {a }}$ \\ ${ }^{a}$ Szent István University, György Enyedi Doctoral School of Regional Sciences, \\ viktoria.jozsa@gmail.com
}

Cite this article: Józsa, V. (2016). Regional processes in Hungary-From PHARE to Smart specialisation. Deturope, 8, 3: 14-32

\begin{abstract}
Europeanisation and regionalization, European convergence versus local divergence are important and timely questions as regards the future of EU cohesion policy, that originally aimed to reduce economic, social and territorial inequalities. Recently, it does not solely support regional development and stimulate modernization processes, but also aims to advance competitiveness, job creation, innovation, and sustainable growth and development (Europe 2020 strategy), especially at the sub-national level. The comparison of regional processes, institutional systems, experience and the originating potential future scenarios of transition economies are interesting but yet under-examined fields of study. Is there a specific way (trajectory) of regionalization in transition economies, or practices vary from country to country? Do EU level policy changes affect national and sub-national level institutions and processes and if yes, for what extent? PHARE programmes were introduced in the early 1990s, short after the change of regime, and following the EU accession, Structural Funds have become the main public financial instruments in these countries, accompanied with a massive foreign direct investment flow. The subsequent EU programming periods and the connected terminology have been predominantly shaping regional policy in these countries; Operational Programmes, Action Plans, Logical Framework Approach, Project fiches, Regional Innovation Strategies, Local Action Groups, Competitiveness Poles, Clustering, Smart Specialisation, Re-industrialisation are only a few keywords that describe this era. The objective of this study is to present a qualitative framework to the evaluation of the period from 1990 to 2015 in Hungary, as a case study of the transition economies, with the identification of the most important milestones and tendencies of regionalization. The relevance of the research is supported by the recent elimination of the NUTS II (regional) level institutional system in the country, and the relocation of ESIF management to the NUTS III (county) level. This process poses the question if Hungary is a trendsetter in Central and Eastern Europe with this practice, or a unique case. The contribution to the state-of-the-art is a qualitative, thorough presentation of the processes, focusing on the administrative and institutional aspects that can on one hand provide a better understanding and secondly, can form an inspiring basis and qualitative methodology for further research on past and future territorial processes and the future of Cohesion policy in the CEE region.
\end{abstract}

Keywords: EU cohesion policy, qualitative evaluation, regionalization, regionalism, Hungary

\section{INTRODUCTION}

Hungary, though being a unitarian country, was a front runner in Central and Eastern Europe as regards the establishment of the legal and institutional framework for regionalization. In 1996, the Act on territorial development and spatial planning was accepted and entered into force. From that time, several modifications were introduced, statistical planning regions were established, regional development councils and agencies were set up and a significant 
capacity and competence development have been realized at the regional (NUTS II) and micro-regional level. This process did not fulfill the expectations about the role of the historically traditional, county (NUTS III) level. A new profession and a scientific discipline have emerged and strengthened. This dynamic tendency resulted several success stories, good and bad examples, a new generation of experts and thousands of implemented EU co-financed development projects with a high absorption capacity, as quantitative indicators. Is it a success story then? Where are we standing now, after more than two decades, what lessons can be learned and what future holds for us? How regionalization could be measured; through an indicator-based methodology (eg. absorption capacity), or through the existence and sustainable operation of regional (NUTS II) level institutions rather? Though Hungary has been characterised by a centralised system from the very beginning of the examined period, the recent elimination of the regional (NUTS II) level from the territorial development institutional system raises important questions that go beyond national boundaries to the direction of the Europeanisation concept (Radaelli, 2003; Ladrech, 2010).

The main motivation is to shed light on recent processes and thus, generate further crosscountry qualitative research in the CEE region in order to identify (1) divergencies from research results exploiting quantitative methods; (2) possible dynamism and future scenarios in policy-making and implementation. The paper is structured into a literature review, objectives and methodology, the presentation of a V4 level outlook, a single country case study and conclusions in the last section.

\section{LITERATURE REVIEW}

There exist some interesting recent studies on the effectiveness and impact of Cohesion Policy in the CEE countries, but these studies either focus on the utilisation of EU funds and absorption capacity with a quantitative methodology (Pálmai, 2014), or combine empirical results and statistical data in order conduct cross-country comparison and identify different patterns and trajectories from the past (Nagyházi, 2015). Other authors have published works on Central and Eastern Europe about regional dynamics (Palermo and Parolari, 2013), regional development agencies (Halkier et al., 1998), decentralization and transition (Kirchner, 1999) and there are some country-specific essays also for the Czech Republic and Slovak Republic (Nemec and Matejová, 2014), Poland and the Czech Republic (Yoder, 2003), and other works on horizontal partnership and patterns of sub-national governance in Poland, the Czech Republic and Hungary (Dabrowski, 2013a), without being exhaustive. The current study is different and yet unique in its single-country, in-depth empirical and 
process-based focus with the identification of the main phases and characteristics of regionalization that can form a sound basis for further, multi-country studies and crosscountry comparisons. As theoretical framework, the author refers to the works of Lorenz and Süli-Zakar as regards conceptual definition, differences and relationship of regionalization and regionalism (Lorenz, 1991; Süli-Zakar, 2005) as summarised below.

Table 1 Differences and Relationship of Regionalism and Regionalization

\begin{tabular}{|c|c|c|c|}
\hline & REGIONALISM & REGIONALIZATION & RELATIONSHIP \\
\hline DESCRIPTION & $\begin{array}{l}\text { - an inter-related system } \\
\text { of permanent natural- } \\
\text { social-economic-cultural } \\
\text { factors } \\
\text { - the deal of equal parties, } \\
\text { constitutes equality }\end{array}$ & $\begin{array}{l}\text { - the neighbouring local } \\
\text { governments establish an } \\
\text { administrative-political } \\
\text { community } \\
\text { - the deal of non-equal } \\
\text { parties, presumes } \\
\text { subjectness }\end{array}$ & $\begin{array}{l}\text { - both definitions mean } \\
\text { geographic integration and are } \\
\text { frequently used as the } \\
\text { opposite of globalization } \\
\text { - both phenomena change } \\
\text { with the ever changing } \\
\text { environment }\end{array}$ \\
\hline $\begin{array}{l}\text { EVOLUTION } \\
\text { PROCESS }\end{array}$ & $\begin{array}{l}\text { - strong economic and } \\
\text { social links result a } \\
\text { homogenous area from } \\
\text { the perspective of } \\
\text { regional structures } \\
\text { - the natural evolution of } \\
\text { objective relations and } \\
\text { networks (bottom-up) }\end{array}$ & $\begin{array}{l}\text { - the willingness of } \\
\text { people creates the } \\
\text { common territorial unit } \\
\text { coordinated by politicians } \\
\text { - coordinated } \\
\text { administrative and } \\
\text { political process } \\
\text { (top-down) }\end{array}$ & $\begin{array}{l}\text { - they can have synergetic } \\
\text { relationship as regionalism } \\
\text { can accelerate political-social- } \\
\text { economic processes and } \\
\text { regionalization can result } \\
\text { democratization that supports } \\
\text { the full evolution of } \\
\text { regionalism }\end{array}$ \\
\hline OBJECTIVE & $\begin{array}{l}\text { - high level integration } \\
\text { between the specific } \\
\text { particles } \\
\text { - horizontal integration }\end{array}$ & $\begin{array}{l}\text { - more advantageous } \\
\text { political position } \\
\text { - vertical integration }\end{array}$ & $\begin{array}{l}\text { - there are substantial linkages } \\
\text { between the two phenomena } \\
\text { while the organization of the } \\
\text { particles significantly differs }\end{array}$ \\
\hline RESULT & $\begin{array}{l}\text { - macroregional } \\
\text { geographic structure that } \\
\text { allows the optimal use of } \\
\text { human, ecological and } \\
\text { economic resources }\end{array}$ & $\begin{array}{l}\text { - increased cooperation } \\
\text { and trust as the } \\
\text { predecessors and real } \\
\text { characteristics of good } \\
\text { governance }\end{array}$ & $\begin{array}{l}\text { - regionalism is the necessary } \\
\text { predecessor of a well- } \\
\text { functioning regionalization }\end{array}$ \\
\hline
\end{tabular}

Source: own construction on the basis of Süli-Zakar (2005) and Lorenz (1991)

\section{OBJECTIVES AND METHODS}

Twenty-five years after the change of the political system, the qualitative analysis of longterm territorial processes in transition economies is an interesting but yet under-examined field of study that deserves attention. How could we characterize and describe the courses of twenty-five years in a single study? Could we call it regionalism, or regionalization instead? Can we underline or contradict quantitative absorption capacity data and research results? Based on quantitative data and key performance indicators, the numbers show good absorption capacity and an efficient allocation of EU co-financing resources. On the other hand, if we operationalize the question in a qualitative way and examine regionalism and/or regionalization processes, sub-national governance and administration capacity, pluralization, 
decentralization the institutionalization at regional level, we may easily discover another side of the same coin.

The objective of this paper is to determine if Hungarian regionalization/regionalism was a success story that predicts a possible future scenario for other CEE countries also.

The relevance of the research is supported by the recent elimination of the NUTS II (regional) level institutional system in the country, posing the main question if Hungary is a trendsetter in Central and Eastern Europe with this practice, or a unique case. The methodology of this contemporary, single case study is qualitative and process-based, building upon real context and empirical research.

Data and information sources are contemporary publicly available content, more specifically reports and studies, publications from organizations involved in territorial development, media, government websites and other special reports, empirical evidence and policy documents. The examined period is twenty-five years, starting from the introduction of the PHARE programs soon after the change of regime, and ending in the present (19902015). The geographical coverage is Hungary, as one of the transition economies and a Member State of the European Union.

The methods of analyzing the evidence were essentially qualitative. The research combined case study analysis and content analysis of policy and programming documents and the examined periodical. The study is explanatory and partly exploratory on the basis of the examined elements and focuses on institutionalization and administrative capacity as regards regionalization. The author identified twelve key dimensions and qualitative characteristics and established a structural classification on that basis (Table 3). Complementary to secondary sources and empirical research, two new elements of analysis were also examined, as firstly all issues (134) of the periodical Village City Region between 1994 and 2014 and their main topics and articles; and secondly the main topics of the Annual Conferences of Hungarian Regional Science Association from 2002. The main selection criterion for these two examined elements was the intention to capture and follow the relationship of regional theory (science) and practice. The periodical Village City Region is the main journal of regional (territorial) development practitioners from 1994 and it has been edited, published, and distributed to a wide audience covering all municipalities, by the all-time Ministry/Authority responsible for the coordination of regional development. Hungarian Regional Science Association is the main (scientific) forum of regional experts with a continuously growing membership, including both academics and practitioners from all territorial levels.

The contribution to the state-of-the-art is a qualitative, thorough presentation of the processes, focusing on the administrative and institutional aspects that can on one hand 
provide a better understanding for the next generation of experts and interested audience and secondly, can form an inspiring basis and qualitative method for further research in the field of past and future territorial processes of Central and Eastern European countries.

\section{RESEARCH RESULTS}

\section{The V4 level}

When taking a look at the Visegrad countries, as a wider geographical scope, we can find different practices for decentralization and regionalization. The following table involves some important facts and data from the V4 countries connected to regionalization.

Table 2 Basic characteristics of V4 countries connected to regionalization (2013)

\begin{tabular}{|c|c|c|c|c|}
\hline & Slovak Republic & Czech Republic & Poland & Hungary \\
\hline NUTS I & national level & national level & 6 regions & 3 regions \\
\hline NUTS II & 4 aggregated regions & 8 cohesion regions & 16 voivodships & 7 regions \\
\hline NUTS III & $\begin{array}{c}8 \text { Higher Territorial } \\
\text { Units (kraj) }\end{array}$ & $\begin{array}{l}14 \text { regions (kraj) } \\
(2001)\end{array}$ & 66 subregions & $\begin{array}{l}19 \text { counties } \\
\text { (megye) }\end{array}$ \\
\hline LAU 1 & 79 districts (okres) & $\begin{array}{l}76 \text { districts (okres) } \\
\text { and } 15 \text { in Prague }\end{array}$ & $\begin{array}{l}314 \text { powiats } \\
65 \text { cities with } \\
\text { powiat status }\end{array}$ & $\begin{array}{l}175 \text { districts } \\
\text { (járás) }\end{array}$ \\
\hline LAU 2 & $\begin{array}{l}2890 \text { municipalities } \\
\text { (obec) } \\
138 \text { towns }(2013)\end{array}$ & $\begin{array}{c}6249 \\
\text { municipalities } \\
(\text { obec }) \\
206 \text { with extended } \\
\text { competence }\end{array}$ & 2479 gminas & $\begin{array}{c}3154 \\
\text { municipalities } \\
\text { including } 328 \\
\text { cities }\end{array}$ \\
\hline $\begin{array}{l}\text { Administrative (self- } \\
\text { governing) regions }\end{array}$ & no & no & yes & no \\
\hline Regional authorities & yes (52) & yes & $\begin{array}{c}\text { yes }(66) \\
1991-1995\end{array}$ & yes \\
\hline $\begin{array}{l}\text { Legislative } \\
\text { background }\end{array}$ & $\begin{array}{c}\text { Resolution } 738 / 2000 \\
\text { on RDAs } \\
\text { Act No. 539/2008 } \\
\text { on regional } \\
\text { development }\end{array}$ & $\begin{array}{c}\text { Article } 99 \text { of the } \\
\text { Constitution } \\
183 / 2006 \text { Act } \\
\text { Act } 129 / 2000 \text { on } \\
\text { regions } \\
561 / 2006 \\
\text { Spatial } \\
\text { Development } \\
\text { Policy }\end{array}$ & $\begin{array}{l}1990 \text { local self- } \\
\text { governments } \\
1998 \text { regional self- } \\
\text { government } \\
\text { Act } 48 / 2000 \text { on } \\
\text { Regional } \\
\text { development } \\
\text { support }\end{array}$ & $\begin{array}{c}\text { Act on } \\
\text { Territorial } \\
\text { Development } \\
\text { (1996) }\end{array}$ \\
\hline Responsible ministry & $\begin{array}{c}\text { Ministry of } \\
\text { Transport, } \\
\text { Construction and } \\
\text { Regional } \\
\text { Development }\end{array}$ & $\begin{array}{l}\text { Ministry of } \\
\text { Regional } \\
\text { Development }\end{array}$ & $\begin{array}{l}\text { Ministry of } \\
\text { Regional } \\
\text { Development }\end{array}$ & $\begin{array}{l}\text { Ministry for } \\
\text { National } \\
\text { Economy }\end{array}$ \\
\hline
\end{tabular}

Source: own construction on the basis of public data from 2013, 2016 
Slovakia and the Czech Republic are often characterized with a decentralized Unitarian model, and Poland with a regionalized one, while Hungary has a unitarian structure (EGTC, 2009). It can be stated that various territorial self-government and regional development systems have emerged in the V4 countries as answers to the requirements of place-specific development of EU Cohesion Policy. In the first programming period (2004-2006), as a topdown policy pressure, the European Commission opted for centralised management of EU funding, that resulted a single (integrated) regional Operational Programme in these countries accompanied by significant disappointment in both scientific and practitioner communities. Between 2007-2013, the introduction of ROPs (Regional Operational Programmes) for each NUTS II region ensured the prerequisites of regional capacity building and the diffusion of multi-annual strategic planning of developmental initiatives at regional and local levels (Dabrowski, 2012). According to research results of a recent study, that completed a V4 level comparison on regional development trends and institutional environment, the Czech Republic could be characterized with a learning process between 2004 and 2006; and a fullscale programme implementation between 2007-2013 with an important and growing role of regional self-governments. The territorial differences are the least significant compared to other V4 countries. Slovakia had not implemented ROP in its first cohesion period and has been implementing a single ROP in 2007-2013. Its territorial disparities are among the largest in the V4 group and Eastern Slovakia is still falling back visibly. As regards Poland, in spite of growing regional disparities between 1995 and 2009, recent development processes show relatively stable development disparities apart from a still significant difference between the capital region and the rest of the regions (Nagyházi, 2015). It is interesting to point out that while the referred author (using a rather quantitative methodology) recently labelled the Czech Republic and Poland as good examples for consensus based decentralization processes, Dabrowski (on the basis of empirical research) stated in 2013 that regional programming was undermined by strong central control in these two countries (Dabrowski, 2013.a). This contradiction illustrates well the potential difference between the research results of qualitative and quantitative research that the current paper also emphasizes.

As it is clear from literature and practice also, preliminary implementation processes (institutional and territorial regionalization) of Cohesion Policy were rather uneven in case of the CEE countries as EU policy lacked detailed description of regionalization processes (Hughes et al., 2004). Though regionalization was a mandatory exercise to be completed in connection to the EU accession, regional and supra-national priorities are not always in sync that is mainly caused by the gatekeeping role of central governments (Ghita, 2013). This 
phenomenon could be identified in the presented case study also. Several other authors have already identified that 'shallow' adjustment to strategic regional planning requirements and 'shallow' Europeanisation (Czrenielewska et al., 2004) may result in non-strategic use of the European Strategic and Investment Funds (ESIF) and limit the effectiveness and efficiency of EU Cohesion Policy. As an addition to this issue, European convergence versus local divergence is a phenomenon that is very characteristic in CEE countries. It means that while the peripheries of the EU have shown remarkable growth in terms of GDP, that predicts a successful convergence process, territorial inequalities within the countries are not decreasing (Török, 2013).

In case of Hungary, regionalization and the connected regional level institutionalization have been started and implemented and all of that resulted good absorption indicators. On the other hand, these processes have been stopped radically by the end of 2015 . This process clearly does not contribute to a more strategic and place-specific use of ESIF. Though it was an unexpected action that lacked social and territorial consensus, it has to be highlighted that compared to other Visegrad countries, the management of regional development policies has been very frequently restructured in the central government in Hungary (Rechnitzer and Smaho 2011).

\section{The Hungarian case study}

Starting with the regulatory background, territorial (regional) development is regulated in Hungary by the Act on Territorial Development and Spatial Planning (XXI/1996). The objective of the act was to define the main tasks and regulations connected to territorial development and spatial planning and to establish its institutional system. This act was first modified in 1999, with the aim to establish the NUTS II level statistical and planning regions and the connected regional institutional and governance system, required for the accession of the country to the European Union. With the second modification in 2004, micro-regional councils as new players came into the picture. It has to be highlighted, that micro-regional players and associations have been actively self-organised themselves before 2004 also, as good examples of bottom-up initiatives. A major modification was made in 2011 when the institutional system of territorial development was significantly modified and as a result, from 1 January 2012, territorial and spatial development competences were re-located to the county (NUTS III) level. The latest modification was completed in 2013, whereas even the definition of "region" was modified. From 2016, the management of ESIF funds was relocated to the county (NUTS III level) with the elimination of the regional development agencies (RDA). 
While Rechnitzer identified four phases in the analysis of regional policy and regionalization in Hungary (Rechnitzer, 2012), the author divided the examined period between the early 1990s and 2015 into three phases based on research results that will be presented in the next sub-sections (Figure 1).

Figure 1 Interpretation of Regionalization in Hungary (1990-2015)

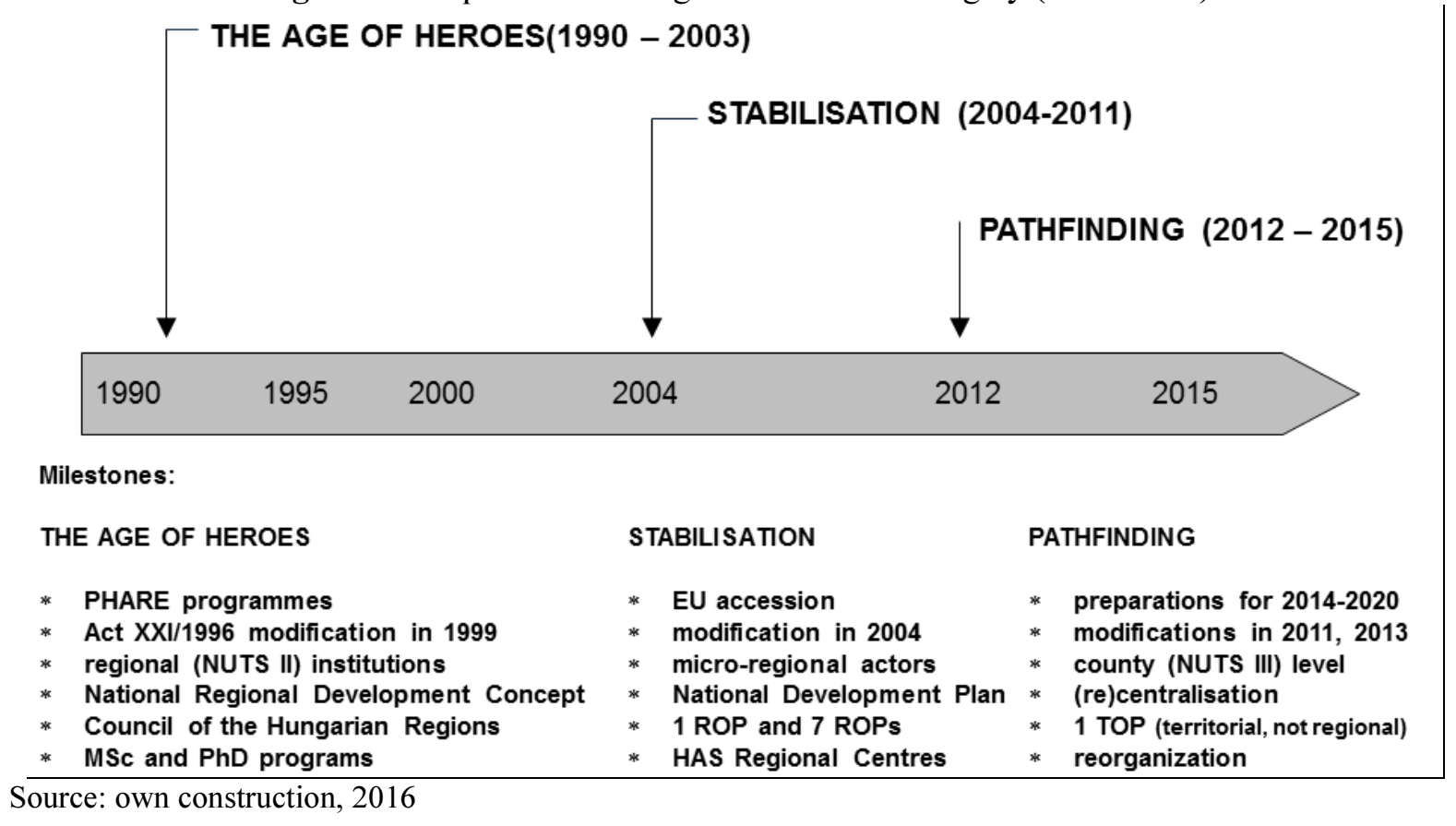

\section{The Age of Heroes (1992 - 2003)}

PHARE (Pologne, Hongrie Aide a la Reconstruction Économique) institutional development programmes have been introduced in the early 1990s as part of the so-called pre-accession funds (PHARE, SAPARD and ISPA).

Institutionalisation has been started at the regional level, including the decision-making (Regional Development Councils, RDCs) and operational (Regional Development Agencies, RDAs) institutions also. Significant administrative capacity building characterized this period that can be described with the phrase "the beginners of today are the leaders of tomorrow". At the national level coordination, the National Regional Development Council was established (1996) and an important policy document, the National Territorial Development Concept was elaborated in 1998. The number of actors has been continuously increasing, professional contacts have been intensified and several national and international events were organized, facilitating the exchange of information.

As regards international presence, an important milestone of integration into the international bloodstream was the establishment of the Representation of the Hungarian Regions in Brussels. The initiative was unique, as in the late 1990s, integrated regional 
representation of Member States and the connected divided infrastructure model was not typical. Lateron, this model served as precedent for the Czech and Slovak Houses (Balogh, 2008). The representation has been fulfilling pioneering tasks as providing regular reports from Brussels and organization of study tours and trainings for regional representatives. Two outstandingly important organizations should be also mentioned here, firstly the national level VÁTI Urban Planning Institute and at the EU level, the European Association of Development Agencies (EURADA) that had an outstanding role in the preparation and support of Hungarian regions.

Regarding administrative capacities, the financial and institutional background of Hungarian regions, additionally to the various decentralised national budgetary funds (eg.: TEKI, CÉDE), extended financial sources have been allocated to the regional level from 2001 and in September 2000, the Conciliatory Council of the Hungarian Regions (TERET) was established. The members of TERET were the Presidents of the Regional Development Councils and its twofold objective was to enhance the preparation of Hungarian regions to EU accession and to strengthen the participation of regional actors in the allocation, and thus, absorption processes of national financial sources (VÁTI, 2005). The evaluation of the effectiveness and impacts of PHARE programs is not an objective of this study, but it should be highlighted, that the training and preparation of actors in the Hungarian territorial development institutional system at national, regional, micro-regional and local level through "learning by doing" and good practice transfer, have laid the foundations of Hungary's successful EU accession. Furthermore, the program has contributed significantly to Hungarian decentralization processes and the generation of territorial and thematic partnerships and cooperation (Polgár, 2007). With the preparation of the National Development Plan and establishment of the Managing Authorities, Intermediary Bodies and Programme Monitoring Committees, PHARE programs have reached their final aims and were officially closed. Higher education in regional development has been started also at several institutions. As regards the examined periodical, PHARE Newsletter has become a regular column and from 2001, Rural Development was introduced as a separate heading. This correlates to the launching of LEADER (Liaison Entre Actions pour le Development de l'Economie Rurale) community initiative, firstly as a pilot program, later on as part of the Agricultural and Rural Development Operational Programme. In the decentralized implementation of LEADER and the development of rural economies, Local Action Groups have played a major role. Between 1994-1999, reports from the World Habitat Days and international conferences, presentations of good practices, annexes, investment magazines, articles on urbanism, Pro Region Awards 
were determinate. From 2000, articles on regionalism and regionalization have appeared and a report from the first National Forum of Regional Development Agencies in 2002. The last year before the accession was characterized by outstandingly intensive activity, the launching of a new column 'News from the EU'.

In this period, a large number of practitioners have struggled with the weight of professional responsibility during the translation of "project fiches" (project summary data sheets adapted for PHARE), the preparation of policy documents and logical framework matrices, strategic programming activities and background reports for decision-making, but they met these challenges and contributed decisively to successful EU accession.

\section{Stabilisation (2004 - 2011)}

Hungary accessed the European Union on 1 May 2004 and this event brought significant changes in the institutional system also. The 'short' programming period between 2004-2006 has been started, including the implementation of the first National Development Plan (NDP) and the single (integrated) Regional Operational Programme (ROP).

Institutionally, the regional institutional framework was accredited and has started functioning, Managing Authorities (MAs) and Intermediary Bodies (IBs) were coordinated by sectoral ministries. System operation has dredged up some problematic points that were reregulated by the modification of the Act in 2004. Though have been frequent changes in the central coordination of regional development, significant milestones of regionalization were the launching of the seven separate Regional Operational Programmes in 2007 and the new National Territorial development Concept in 2005.

As regards administrative capacity, a dynamic increase is well-identified in a national survey, reporting 298 employees as regional level staff members in 2004. Stable infrastructural background supported the operation of regional organizations, mainly regional development agencies, and the so-called Competitiveness Pole Programme was launched in 2005 , as an initiative focusing on the strengthening of regional capitals as growth poles with spatial spillover effects. Though the assessment of the Pole Programme between professionals is ambivalent, two facts are indubitable: the clusters established in that period constitute the backbone of good practices of our days; and no other program similar in complexity, scale, approach and focus has been introduced since that time.

Regarding international presence, the Representation of Hungarian Regions in Brussels was established in a renewed form and represented the interests of all seven regions. One important international organisation should be mentioned in line with the specialisation 
processes in regional development, namely the Network of Innovating Regions in Europe (IRE). This organisation enhanced the integration of Hungarian regions into international programmes, with special respect to the Research and Technological Development Framework Programmes of the EU. European Grouping of Territorial Cooperation (EGTC) was an initiative launched in 2006, that further colored the picture. Its objective was to advance interregional and transnational cooperations of regional and local authorities that could lead to increased coordination, knowledge and good practice exchange. In March 2010, the Lisbon Strategy was replaced by Europe 2020 Strategy for Smart, Sustainable and Inclusive Growth. This EU level strategy identified new priorities for territorial development and its actors.

As regards the examined periodical, soon after the accession in 2004, the Communication from the Directorate-General for Regional Policy on EU accession was published. Advertisements have appeared connected to ROP training programs, e-government, and the first advertisements from private consultancy companies for proposal writing also emerged. In 2006, main topics were the ten-year old territorial development institutional system, spatial planning, preparations for the next EU programming period and comparison studies between present reality and future opportunities. In 2007, main topics were the closure of PHARE Programme with the title 'Farewell to the Lighthouse' and the first ex-post evaluation results of the 'short' programming period.

In this period, the "dilution" of craft was a common opinion, the number of proposal writing companies were replicated in a short period, the community of professionals was splitting up to "Veterans" and "Titans". The specialization in innovation and research and development is an important tendency to identify, going hand in hand with the elaboration of regional innovation strategies and the establishment of Regional Innovation Councils and Agencies from 2004. The vertical tension and opposition between regional and county levels have been dissolved and a system-level (co)operation has been started that could be considered as efficient.

\section{Pathfinding (2012 - 2015)}

The current period in Hungarian territorial development was started with a "kaikaku" (meaning 'radical change' in Japanese '5S methods' used in management consulting), and from that time, a continuous pathfinding can be experienced. We can lay down that several processes required immediate intervention. Among others, these processes were the excessive concentration of decision making power and competences (National Development Agency), 
the acceleration of subsidy allocation, the signing of the Grant Agreements and the start of preparation for the 2014-2020 EU programming period. The phasing-out and phasing-in tasks between the EU programming periods were jammed and the global economic crisis did not facilitate strategic programming and the execution of the measures and interventions either. The European Commission has set several new targets and introduced new policies and buzzwords, such as (re)industrialisation, (re)shoring, smart specialization, Europe 2020, triple, quadruple, quintuple and n-tuple helix models, smart cities, sustainable development, integrated programming, CLLDs and ITIs.

Institutionally, the Office for National Economic Planning was established and removed (2012-2014), Managing Authorities belong again to sectoral ministries, the National Development Agency was abolished. There is only one 'decentralised' Territorial and Settlement Development Operational Programme (TOP) for convergence regions and its Intermediary Bodies have recently formulated on NUTS III level.

As regards administrative capacity, there is a clear (partly re-)allocation of resources to the NUTS III (county) level and a new player, the Széchenyi Programme Office and its regional branches have been operating from November 2012 as background institution of the Prime Minister's Office. This Office operates a Representation in Brussels from mid-2013. Regional Development Councils were eliminated from the system by 31 December 2014 and Regional Development Agencies by 1 January 2016. Counties and cities with county rank are planned to receive significant resources from TOP in the policy framework of the so-called Modern Cities Programme, coordinated from the national level. The supporting legislative background, two modifications in this relatively short period, re-arranged the institutional puzzle. The National Regional Development Council was replaced by the National Territorial Development Conciliatory Forum that forms the framework for consultations between the national and sub-national governments, down to city with county rank level. In parallel, the new EU programming period was started but until the third quarter of 2015 only a few calls for proposals were published. As a conclusion, it can be stated that the current decision of the central government is not clearly advancing Europeanisation and the 'added value' of Cohesion Policy, namely the institutionalization of strategic planning, has been at least reduced if not eliminated.

The examined periodical reacted to the changes also; several reputed authors have published debate opener articles in its issue in the second half of 2011. These writings are connected to EU programming period 2014-2020 and include also Horkay's study that urged 
a paradigm and paradogma change in national development policy (see also Ángyán, Boros, Csatári, Csizmadia, Faragó, Horváth, Nyikos, Szaló and Horkay, 2011). The author's identification of the phases of regionalization is supported by the sudden and drastic decrease in the issues of the examined periodical as starting from yearly 8-10 issues between 1994 and 2004, with a yearly average of 3 issues between 2004-2011, there were no issues published in 2013, 2015 and 2016. Specialization strengthened towards local economic development and development of farmsteads, rural economies, community building, free entrepreneurial zones, EGTCs connected to ITIs (Integrated Territorial Investments) and indigenous development got boost. Smart specialisation, triple and n-tuple helices, (re)industrialisation, CLLDs and ITIs have become the new keywords, methods and objectives of strategic programming.

\section{Relationship of Theory and Practice}

Rigid separation of regional science and practice is not reasonable; neither on organisational, nor on professional level. In most cases, colleagues of academic and research organisations play an active role in technical tasks. The Centre for Regional Studies of the Hungarian Academy of Sciences was established in 1984 (currently it is called Centre for Economic and Regional Studies) and it launched its scientific periodical in 1987, with the title 'Space and Society'. As its President of the Editorial Board, György Enyedi formulated in the foreword of the first issue, Space and Society "is not distributing the research results of a single scientific discipline, but a problem: it examines the relationship of space and society from the aspects of different scientific disciplines, with a specific approach.” (Enyedi, 1987).

As regards the first phase, the 'Age of Heroes', Village City Region periodical was issued for the first time in 1984, and the Hungarian Regional Science Association was established in 2002. Master level education has been started in 1994 and the $\mathrm{PhD}$ program from 1996, as guarantees for permanent supply of new graduates. Science and practice have engaged on several points, such as strategic programming, the preparation of policies and programs (Horváth, 2014) and participation in the training programmes.

In the period of 'Stabilisation' regional science and practice have been cooperating closely. With the EU accession, the integration to European scientific (research) are(n)a has been strengthened, cross-border Hungarian research has emerged as a strategic objective and research of regional processes in Eastern and Southern-Eastern Europe has become a determinate element. The number of cooperative research and joint research projects has increased continuously and their partnership was widened with economic actors. 
'Pathfinding' could be characterized by centralization; according to Horváth, territorial development has become a weightless policy, almost all prerequisites of decentralized operation were eliminated and most of the results of twenty-five years of science organization was wasted (Horváth, 2014). The elimination of regional level from territorial development institutional system has raised questions connected to the reasonableness of regional sciences as a separate scientific discipline. As Nemes Nagy writes in Enyedi's scientific biography; "The Regionalist" was arguing in several essays for the existence and role of regional sciences as a separate discipline (Enyedi, 2011, Nemes-Nagy, 2012). As benchmarking data for further cross - country comparisons the author refers to Szabó who counted more than 20 $\mathrm{PhD}$ defenses in regional science between 2008 and 2013 in Hungary and identified 50 departments at 16 higher education institutions in 14 settlements where more than 50 lecturers participate higher education of regional development. The main problems the authors highlighted were the ever changing expectations from the practical side (and thus the suitable curriculum), the deficiencies in practice-oriented education, and in overall, the adaptation problems of higher education to the dynamically changing policy implementation environment (Szabó, 2013).

\section{CONCLUSIONS}

\section{The Hungarian case study}

It can be stated that regionalization has been started in Hungary in the early 1990s with a major contribution of the PHARE program. From that time, decentralization could be observed, while from 2012, there is a tendency towards (re)centralization. Competences formerly allocated and strengthened at the regional level, including ESIF management, are now restructured and relocated to the historical county (NUTS III) level. Regional (NUTS II) level institutions, the Regional Development Councils and Agencies, have been abolished in the near past. While in 2004, professionals were mostly characterized by miracle expectation, in 2014, there have been uncertainties and question marks. The global financial and economic crisis slightly, the changing Hungarian political-social environment, significantly influenced regional processes in the country, those phases and main characteristics are summarized by the author in Table 3. 
Table 3 Characteristics of the Phases of Regionalization (1991-2015)

\begin{tabular}{|c|c|c|c|}
\hline $\begin{array}{l}\text { Characteristics } \\
\text { / phases }\end{array}$ & $\begin{array}{l}\text { 1. The Age of Heroes } \\
(1990-2003)\end{array}$ & $\begin{array}{l}\text { 2. Stabilization } \\
(2004-2011)\end{array}$ & $\begin{array}{l}\text { 3. Pathfinding } \\
\text { (2012-2015) }\end{array}$ \\
\hline $\begin{array}{l}\text { Territorial } \\
\text { processes }\end{array}$ & $\begin{array}{l}\text { first PHARE programs, } \\
\text { regions, micro-regions }\end{array}$ & $\begin{array}{l}\text { failed territorial reform } \\
\text { (IDEA) but decentralization }\end{array}$ & $\begin{array}{l}\text { centralisation, counties, cities } \\
\text { with county rank, districts }\end{array}$ \\
\hline $\begin{array}{l}\text { Legal } \\
\text { background }\end{array}$ & $\begin{array}{l}\text { Act } 21 / 1996 \text { and } \\
\text { modification in } 1999 \\
\text { EU: Lisbon Strategy } \\
(2000)\end{array}$ & $\begin{array}{l}\text { modification in } 2004 \\
\text { EU: Europe } 2020 \text { Strategy } \\
(2010)\end{array}$ & $\begin{array}{l}\text { modifications in } 2011 \text { and } \\
2013\end{array}$ \\
\hline $\begin{array}{l}\text { Relevant policy } \\
\text { (national level) }\end{array}$ & $\begin{array}{l}\text { National Territorial } \\
\text { Development Concept } \\
\text { (NTDC) in } 1998\end{array}$ & $\begin{array}{l}\text { new NTDC in 2005, National } \\
\text { Development Plan, Pole } \\
\text { Programme, New Hungary } \\
\text { Plan and New Széchenyi Plan }\end{array}$ & $\begin{array}{l}\text { Széchenyi } 2020 \\
\text { National Development } 2030 \\
\text { national and county level S3 } \\
\text { strategies }\end{array}$ \\
\hline $\begin{array}{l}\text { Strategic } \\
\text { programming }\end{array}$ & $\begin{array}{l}\text { sectoral versus regional } \\
\text { concepts, NDP + } 1 \text { ROP }\end{array}$ & $\begin{array}{l}1 \text { ROP, good absorption and } \\
7 \text { ROPs (from 2007) }\end{array}$ & $\begin{array}{l}\text { preparations 2014-2020, } 1 \\
\text { TOP, CLLD, ITI, Modern } \\
\text { Cities Programme }\end{array}$ \\
\hline $\begin{array}{l}\text { Institutional } \\
\text { system }\end{array}$ & $\begin{array}{lr}\text { Ministry of } \\
\text { Environment and } \\
\text { Regional Development, } \\
\text { Ministry for Agriculture } \\
\text { and Rural Development, } \\
\text { counties, Teret, 2000), } \\
\text { key role of VÁTI }\end{array}$ & $\begin{array}{l}\text { Ministry for Self-Governance } \\
\text { and Territorial Development } \\
(2006) \text { Ministry for National } \\
\text { Development and Economy } \\
(2008) \text { strong National } \\
\text { Development Agency (NDA), } \\
\text { regions (RDAs), micro- } \\
\text { regional level, EGTC (2006) }\end{array}$ & $\begin{array}{lrr}\text { Ministry for } & \text { National } \\
\text { Economy (TOP Managing } \\
\text { Authority and strategic } \\
\text { planning), sectoral ministries, } \\
\text { Hungarian } & \text { Treasury, } \\
\text { Széchenyi Programme Office }\end{array}$ \\
\hline $\begin{array}{l}\text { Infrastructural } \\
\text { background }\end{array}$ & $\begin{array}{l}\text { heterogeneous, under } \\
\text { formulation }\end{array}$ & outstanding, high quality & $\begin{array}{l}\text { under re-location and re- } \\
\text { structuring }\end{array}$ \\
\hline $\begin{array}{l}\text { Human } \\
\text { resources }\end{array}$ & $\begin{array}{l}\text { dynamically increasing, } \\
\text { cooperative, trainings, } \\
\text { study visits }\end{array}$ & $\begin{array}{l}\text { multi-actor system, } \\
\text { replicated participants }\end{array}$ & under restructuring \\
\hline $\begin{array}{l}\text { International } \\
\text { relations }\end{array}$ & $\begin{array}{ll}\text { Representation } & \text { of } \\
\text { Hungarian Regions } & \text { in } \\
\text { Brussels (1999) } & \end{array}$ & $\begin{array}{l}\text { Representation of Hungarian } \\
\text { Regions in Brussels } 2.0 \\
\text { (2004) plus regional offices }\end{array}$ & $\begin{array}{l}\text { Széchenyi Programme Office } \\
\text { Representation in Brussels } \\
(2013)\end{array}$ \\
\hline $\begin{array}{l}\text { Financial } \\
\text { background }\end{array}$ & $\begin{array}{l}\text { decentralized funds (eg.: } \\
\text { CÉDE), and PHARE }\end{array}$ & $\begin{array}{l}\text { EU and national (2004-2006; } \\
\text { 2007-2013) }\end{array}$ & $\begin{array}{l}\text { EU and national (2007-2013; } \\
\text { 2014-2020) }\end{array}$ \\
\hline Functions & $\begin{array}{l}\text { statistical-planning } \\
\text { regions formulation }\end{array}$ & $\begin{array}{l}\text { specialisation } \\
\text { (innovation) }\end{array}$ & $\begin{array}{l}\text { specialisation } \\
\text { (local economic development) }\end{array}$ \\
\hline $\begin{array}{l}\text { Relationship of } \\
\text { theory and } \\
\text { practice }\end{array}$ & $\begin{array}{l}\text { formulating cooperation, } \\
\text { HAS regional centres, } \\
\text { Space and Society, } \\
\text { Village City Region, } \\
\text { Hungarian Regional } \\
\text { Science Association }\end{array}$ & $\begin{array}{l}\text { good, efficient } \begin{array}{l}\text { cooperation, } \\
\text { relatively } \\
\text { system }\end{array} \\
\text { decentralized }\end{array}$ & $\begin{array}{l}\text { (re)centralisation, pathfinding, } \\
\text { "innovations" in governance }\end{array}$ \\
\hline $\begin{array}{l}\text { Vertical/ } \\
\text { horizontal } \\
\text { relationship }\end{array}$ & $\begin{array}{l}\text { vertical competition, } \\
\text { horizontal cooperation, } \\
\text { counties vs regions }\end{array}$ & $\begin{array}{l}\text { operable and operating } \\
\text { system but competition } \\
\text { between regional centers }\end{array}$ & $\begin{array}{l}\text { horizontal competition on } \\
\text { county and settlement levels, } \\
\text { expectations, plans }\end{array}$ \\
\hline
\end{tabular}

Source: own construction from public data, 2016 
As regards regional processes in the last 25 years in Hungary, they could be characterized as regionalization rather than regionalism, and could be considered as the most important institutionalized attempt towards regionalization in Hungary in the twentieth century. If we consider absorption capacity and quantitative indicators, Hungary could be classified as a good example, but if we look beyond statistics and examine qualitative characteristics, with special respect to Europeanisation, regional level institutionalisation and administrative capacities, it can be stated that the results are ambivalent. At this point, it has to be highlighted that the presented frequent changes and unplanned decisions resulted a situation that some authors described as 'the house built next to its foundation' (Pálné Kovács, 2004; Perger, 2010). Thus, the current process could have also been evaluated as a corrective action if there was a well-prepared substitute or alternative system. On the other hand, the scheduling of the institutional change was relatively optimized as it followed the completion of strategic programming for 2014-2020.

Methodologically, the main tendencies and milestones can be well-identified and followed through the application of the qualitative methodology and the comparative set of characteristics identified by the author. The growing specialization at the EU policy level towards local economic development, innovation, competitiveness and job creation have been identified at the Member State level also in the case study, so a direct and strong effect of EU policy on the MS and sub-national level was justified.

\section{The V4 level - Future scenarios}

When examining possible future scenarios in the V4 countries, new global level regionalization agendas should also be considered, such as metropolitan regions, cityregionalism, agglomeration economies, 'virtual regionalization' without being exhaustive; that are not in line with the administrative region concept, casting a question mark over the notion of cohesive regional development under the conditions of competitiveness (Herrschel, 2010). The definition of regions as 'places of spaces' or, rather the 'places of flows' as raised by Castells, should also be reconsidered (Castells, 1999).

At the EU policy level, it has to be stated that the new focus of Cohesion Policy is largely placed on growth creation (local (LAU) level) and as growth is a cumulative process that tends to concentrate both spatially, economically and socially, new ways should be explored in order to promote cohesion in Europe. Growing regional disparities between the capital city(region) and the rest of the country is a typical CEE, and thus V4, phenomenon. As a conclusion, it can be stated that the changing focus of EU Cohesion Policy has a potential to 
advance processes also in the CEE region, that are not supporting regionalization in its traditional understanding, but could generate and strengthen new conceptual avenues. In this meaning, the Hungarian case could be considered as the first sign or appearance of these new concepts.

Poland has the strongest institutionalized and administrative regions in the V4, as a regionalized unitarian country, so it is hardly probable that its regionalized system will be revised and/or modified before 2020, especially if we take into consideration the own financial income, property and assets of the voivodships. On the other hand, Slovakia and the Czech Republic, as decentralized unitarian countries, have a significant potential to follow the Hungarian example in the forthcoming years, and revise their regional institutional system, with special respect to the relocation of the competences connected to the management of ESIF funds. With strengthening specialization towards local economic development, innovation, competitiveness and job creation, even the rethinking of inner and external peripheries and the concept of multi-node (city-region) cross-border economic zones could be widely introduced. The 'Europe of the Regions' concept has been clearly shifted to the 'Europe of Cities/Cityregions' direction. The answer to the basic question if Hungary is a trendsetter or a unique case in the V4, or with a wider scope, in the CEE region as regards regionalization, depends largely on the capability of EU Cohesion Policy to meet its current and future global level challenges.

\section{REFERENCES}

Ángyán, J. (2011). Hazai kormányzati stratégiai elvárások a 2014-2020-as programciklusban: vidékfejlesztés. Falu Város Régió, 2011/2. pp. 16-21

Balogh, Z. (2008). Az új regionalizmus svéd modelljeinek alkalmazhatósága Magyarországon. Budapesti Corvinus Egyetem Gazdálkodástani Ph.D. Program, Ph.D. értekezés, 2008

Boros, I. (2011). EU 2014-2020: két vétized útravaló tanulságai. Falu Város Régió, 2011/2. pp. 66-70.

Castells, M. (1999). Grassrooting the Space of Flows. Urban Geography, 20(4) Special Issue: Cities and Telecommunications at the Millennium's End pp. 294-302. DOI: 10.2747/0272-3638.20.4.294

Csatári, B. (2011). Vitára szánt felvetések a Magyar területi- és vidéktervezés (-fejlesztés) közeljövőjét illetően. Falu Város Régió, 2011/2. pp. 42-44.

Csizmadia, N. (2011). Megújuló nemzetgazdasági tervezés Magyarországon. Falu Város Régió, 2011/2. pp. 25-34.

Czernielewska, M., Paraskevopoulos, C., \& Szlachta, J. (2004). 'The regionalization process in Poland: An example of 'Shallow' Europeanization? Regional and Federal Studies 14(3), pp. 461-496 
Dabrowski, M. (2013.a). EU cohesion policy, horizontal partnership and the patterns of subnational governance: Insights from Central and Eastern Europe. European Urban and Regional Studies, DOI: 10.1177/0969776413481983

Dabrowski, M. (2012). Towards strategic regional development planning in Central and Eastern Europe? Regional Insights 3(2), 6-8. ISSN 2042-9843

Enyedi, Gy. (1987). Tér és Társadalom, 1. évf. 1987/1. pp. 3-4

Enyedi, Gy. (2011). Mi a regionális tudomány? Magyar Tudomány, 12, pp. 1514

Faragó, L. (2011). Stratégiai programozás 2014-2020, magyar teendők. Falu Város Régió, 2011/2. pp. 53-57.

Ghita, A. F. (2013). Cohesion Policy vs rregionalization an unexpected inner conflict? Regional Insights Vol. 4 Issue 1 pp. 12-14 DOI: 10.1080/20429843.2013.10708714

Halkier, H., Danson, M., \& Damborg, C. (1998). Regional Development agencies in Europe, Jessica Kingsley Publishers, p. 13-25 (Regional Policy and Development Series; No. 21).

Herrschel, T, (2010). Regionalisation, marginalisation and the role of governance in Europe and North America (Part 2). Regions, No 280 Winter 2010, pp. 28

Horkay, N. (2011). Paradigma- és paradogmaváltás szükséges 2014-2020-ra a Magyar Nemzeti Fejlesztéspolitikában. Falu Város Régió, 2011/2. pp. 71-76

Horváth, Gy. (2011). Szempontok a Magyar területfejlesztés megújításához az uniós változások tükrében. Falu Város Régió, 2011/2. pp. 45-52.

Horváth, Gy. (2014). A Regionális Kutatások Központjának harminc éve - Sikerek és kudarcok egy új tudományágazat megteremtésében. Tér és társadalom, 2014/4., pp. 314

Hughes, J., Sasse, G., \& Gordon, C. (2004). Europeanisation and Regionalization in the EU's Enlargement to Central and Eastern Europe - The Myth of Conditionality. Basingstoke: Palgrave Macmillan ISBN 978-0-230-50318-2

Kirchner, E.J. (1999). Decentralization and Transition in the Visegrad Poland, Hungary, the Czech Republic and Slovakia. Basingstoke: Macmillan; New York: St. Martin's Press, 1999. p. 237. DOI10.1057/9780230374645

Ladrech, R. (2010). Europeanization and National Politics, Basingstoke: Palgrave Macmillan. Chapter 1.

Lorenz, D. (1991). Regionalisation versus Regionalism - Problems of Change in the World Economy. Intereconomics. 26(1), pp. 3-10

Nagyházi, Gy. (2015). Regional development trends and the regional development institutions in the Visegrad countries - enabling or hindering institutional environment? DETUROPE 7(2), 28-44 ISSN: 1821-2506

Nemec, J., \& Matejová, L. (2014). Decentralisation and Quality of Governance: Selected Issues from the Czech and Slovak Republic. BULLETIN OF TARAS SHEVCHENKO NATIONAL UNIVERSITY OF KYIV. ECONOMICS, Kyjev: Taras Shevchenko National University of Kyiv. Neuveden, s. 26-33. ISSN 1728-2667.

Nemes Nagy, J. (2012). Enyedi György, a regionalista. Területi Statisztika 15. (52.) évfolyam, pp. 565-567

Nyikos, Gy. (2011). Mi várható az EU 2014-2020-as fejlesztési ciklusában? Falu Város Régió Issue 2011/2. p. 4.

Palermo, F., \& Parolari, S. (2013). Regional Dynamics in Central and Eastern Europe, New Approaches to Decentralization. Leiden, Boston. Martinus Nijhoff Publishers. 257 p. ISBN: 978-90-04-24231-9 (e-book)

Pálmai, É. (2014). Evaluation of using EU funding sources in the Regional Operative Programmes DETUROPE Vol. 6. Issues 3. pp. 85-96 ISSN: 1821-2506 
Pálné Kovács, I. (2004). A regionális gazdaságfejlesztés igazgatási összefüggései. (The Connection between Regional Economic Development and Public Administration.) in: Pálné Kovács, I. szerk: Versenyképesség és igazgatás. MTA RKK, Pécs, 11-34.

Perger, É. (2010) Az „Alapok” mellé épült ház. Az EU támogatásokkal kapcsolatos intézményrendszer a magyar közigazgatási struktúrában. (The House Built Next to its Foundation, The EU Funds' Management System in the Hungarian Public Administration Structures.) in: Szigeti E (szerk.): „NYAKTAGI tanulmányok. Kitekintés a közigazgatás müködésének jogi, szervezeti és térszerkezeti kereteire". ECOSTAT, időszaki-közlemények 36. Budapest, 245-338

Polgár, T. (2007). A Phare hatása a regionális intézményrendszer fejlődésére. Available at: www.vati.hu/files/articleUploads/.../polgar_tibor_pharehataspolgart.ppt

Radaelli, C. (2003). 'The Europeanization of Public Policy', in Featherstone, K. and Radaelli, C. (2003) (eds.), The Politics of Europeanization, Oxford: Oxford University Press, pp. 27-56

Rechnitzer, J., \& Smahó, M. (2011). Területi politika. Akadémiai Kiadó, Budapest

Rechnitzer, J. (2012). A területi politika és az új állam - Egy elfeledett szakpolitika álmai. Magyar Regionális Tudományi Társaság Konferencia Győr, 2012. november 22. előadás

Süli-Zakar, I. (2005). Régió, regionalizmus és regionalizáció. TERD (The Impact of Tertiary Education on Regional Development program

Szabó, P., Gyurkovics, J., Jancsó, T., Lukovics, M., \& Schwertner, J. (2013). Some features of education of regional policy in Hungarian higher education in the early 2010s. DETUROPE 6:2 pp. 109-120

Szaló, P. (2011). A településfejlesztés kihívásai a 2014-2020-as programciklusban. Falu Város Régió, 2011/2. pp. 22-24.

Török, I. (2013). Regional development in Romania: Shaping European convergence and local divergence. Regions Magazine, 291:1, pp. 25-27.

VÁTI jelentés (2005). elérhető: http://www.vati.hu/static/otk/int/jelentes2005294.pdf

Yoder, J. (2003). A. Decentralisation and Regionalisation after Communism: Administrative and Territorial Reform in Poland and the Czech Republic. Europe Asia Studies 03/2003; 55(2):263-286. DOI: 10.1080/0966813032000055877

1996. évi XXI. törvény a területfejlesztésről és a területrendezésről Available at:: http://net.jogtar.hu/jr/gen/hjegy_doc.cgi?docid=99600021.TV\#lbj7idf7ae

2004. évi LXXV. törvény a területfejlesztésről és a területrendezésről Available at: http://mkogy.jogtar.hu/?page=show\&docid=a0400075.TV

2013. évi CCXVI. törvény a területfejlesztésről és a területrendezésről s Available at: Magyar Közlöny; 2013. évi 208. szám, 2013. december 13. pp. 84575-84583

The European Grouping of Territorial Cooperation (2009). State of play and prospects. Available at: http://cor.europa.eu/en/documentation/studies/Documents/EGTC-state-ofplay/EGTC-state_of_play_and_prospects_EN.pdf 